\title{
MICROBIOLOGICAL CHARACTERISTICS OF SUSHI ACQUIRED IN ESTABLISHMENTS THAT SELL JAPANESE FOOD
}

\author{
CARACTERÍSTICAS MICROBIOLÓGICAS DE SUSHIS ADQUIRIDOS EM \\ ESTABELECIMENTOS QUE COMERCIALIZAM COMIDA JAPONESA
}

\author{
R. A. SATO ${ }^{1 *}$, O. D. ROSSI JUNIOR ${ }^{1}$, K. P. BÜRGER ${ }^{1}$, P. M. ÉVORA ${ }^{1}$
}

\begin{abstract}
SUMMARY
Food quality control refers to all and any action aimed at improving good practice in hygiene procedures and food handling. Therefore, there is a continuous need to obtain data, study and monitor the production and marketing in food industry thus producing a safe food, free from any contamination that may cause damage to the consumer's health. So this study evaluated the microbiological quality of sushi bought in two types of establishments: 15 restaurants specialized in Japanese food and 15 non-specialized restaurants from the Ribeirão Preto - SP region . The populations of heterotrophic mesophiles and psychrotrophic microorganisms ranged from $3,9 \times 10^{2}$ to $1,7 \times 10^{7} \mathrm{CFU} \cdot \mathrm{g}^{-1}$ and $7,5 \times 10^{2}$ to $1,4 \times 10^{9} \mathrm{CFU}_{\mathrm{g}^{-1}}$, respectively. All samples presented Staphylococcus spp. with populations ranging from $2,0 \mathrm{x} 10^{2}$ to $3,8 \times 10^{5} \mathrm{CFU} . \mathrm{g}^{-1}$, where $23,3 \%$ were classified as positive coagulase Staphylococcus and $13.3 \%$ had population values above the established limit. Thermotolerant coliforms were found in $60,0 \%$ of the samples and $33,3 \%$ of them were above the established thermotolerant coliform limit. The presence of Staphylococcus aureus and Escherichia coli were identified in $16,7 \%$ and $30,0 \%$ of the samples, respectively. Salmonella sp. and Vibrio parahaemolyticus were not isolated in this research. There was no difference in the microbiological quality of sushi offered between the two types of establishments. According to the results it is concluded that sushi is a potential foodborne disease food and the nonstandard samples reflect the need to properly train the food handlers.
\end{abstract}

KEY-WORDS: Escherichia coli. Mesophiles. Microbiology. Psychrotrophic. Salmon. Staphylococcus aureus.

\section{RESUMO}

Com o crescimento do consumo da comida japonesa no Brasil surge a preocupação com doenças de origem alimentar relacionadas à ingestão do pescado cru e erros de manipulação desse tipo de alimentos. Diante dessa realidade, esse trabalho avaliou a qualidade microbiológica de sushis adquiridos em dois tipo de estabelecimentos: 15 restaurantes especializados em comida japonesa e 15 restaurantes não especializados da região de Ribeirão Preto - SP. Quantificouse microrganismos mesófilos, psicrotróficos, coliformes termotolerantes, Staphylococcus spp. e S. aureus, Escherichia coli, presença da Salmonella sp. e do Vibrio parahaemolyticus. As populações de microrganismos heterotróficos mesófilos e psicrotróficos variaram de $10^{2}$ a $10^{7}$ UFC.g ${ }^{-1}$ e $10^{2}$ a $10^{9}$ UFC.g $^{-1}$, respectivamente. Todas as amostras analisadas apresentaram Staphylococcus spp. com populações variando de $10^{2}$ a $10^{5}$ UFC.g ${ }^{-1}$, sendo que $23,3 \%$ foram caracterizados como Staphylococcus coagulase positivo e 13,3\% apresentaram valores de populações acima do limite estabelecido pela legislação vigente para pescado cru. Foram encontrados coliformes termotolerantes em $60,0 \%$ das amostras e 33,3\% destas estavam acima do limite estabelecido. As presenças de Staphylococcus aureus e Escherichia coli foram identificadas em 16,7\% e 30,0\% das amostras, respectivamente. Salmonella spp. e Vibrio parahaemolyticus não foram isoladas nesse trabalho. Não houve diferença na qualidade microbiológica de sushis oferecidos entre os dois tipos de estabelecimentos. De acordo com os resultados conclui-se que o sushi é um alimento com potencial de veiculação de doenças de origem alimentar e as amostras fora do padrão refletem a necessidade de treinar adequadamente os manipuladores de alimento.

PALAVRAS-CHAVE: Escherichia coli. Mesófilos. Microbiologia. Psicrotróficos. Salmão. Staphylococcus aureus.

${ }^{1}$ Universidade Estadual Paulista - UNESP - Câmpus de Jaboticabal. E-mail.: rafaelsato.vet@gmail.com 


\section{INTRODUCTION}

The gastronomic sector in Brazil offers a wide variety of cuisine and is responsible for generating many direct jobs in the country. Within this sector, sushi bars, fast-foods and restaurants specialized in Japanese food have been highlighted by the growth in the number of establishments that offer this type of service. This growth is due to the popularization of Japanese food, which currently has the status of being healthy and nutritious, therefore conquering new adepts.

The traditional Japanese cuisine is worldwide known for the habit of consuming raw or in natura fish. However, from the Public Health's point of view, in natura ingredient generates a concern related to foodborne diseases.

Foodborne diseases occur when an individual ingests food contaminated with infectious or toxic agents that he is already ingesting. Among the potentially pathogenic microorganisms that can be transmitted through raw fish, we can mention Aeromonas sp., Escherichia coli, Salmonella sp., Pseudomonas sp., Staphylococcus aureus, Vibrio cholerae and Vibrio parahaemolyticus.

Given the growth in Japanese food consumption combined with food contamination risks during production, storage and sale, there is a preoccupation with the quality of products sold in specialized and non-specialized stores. Thus, the present study aimed to evaluate the microbiological characteristics of sushi sold in restaurants specialized in Japanese food and in non-specialized establishments by quantifying the presence of mesophilic and psychrotrophic microorganisms; total and thermotolerant coliforms; Staphylococcus sp. and S. aureus; Escherichia coli; Vibrio parahaemolyticus and Salmonella spp. and to compare the results with preestablished quality parameters for raw fish from the current legislation.

\section{MATERIAL AND METHODS}

The study was performed on 30 samples of in natura sushi consisting of seasoned rice and salmon (Salmo salar), which may present other ingredients such as algae, sauces and vegetables, preserved refrigerated. Samples were collected from fifteen restaurants specialized in Japanese food and fifteen non-specialized commercial establishments and a sample was acquired from each location.

The specialized establishments were characterized as restaurants that only work with Japanese cuisine, usually offering the customer the service of "all you can eat", "a la carte" or "selfservice" per kilo. The non-specialized establishments category included ordinary restaurants (fast foods, selfservices, steakhouses, etc.) that daily offer to customers traditional Brazilian food, but also incorporate other types of cuisine into the menu.

The samples were collected from the cities Jaboticabal - SP, Ribeirão Preto - SP and Monte Alto SP. The quantities of sushi acquired varied according to the menu offered by the chosen establishment. When the establishment offered the option to sell by weight, approximately $400 \mathrm{~g}$ of sushi were weighed for purchase and all samples were packed in the ordinary form of sale to the consumer.

Immediately after purchase the samples were conditioned in isothermal boxes containing blocks of ice, and taken to the Laboratory of Microbiological Analysis of Animal-derived Food and Water of the Department of Preventive Veterinary Medicine and Animal Reproduction of the FCAV / Unesp, where they were submitted to quantification of mesophilic and psychrotrophic microorganisms, thermotolerant coliforms, Staphylococcus sp. and S. aureus, Escherichia coli and presence of Vibrio parahaemolyticus and Salmonella sp.. The methodologies described in the American Public Health Association (APHA, 2001) were used for analyzes. For the statistical analysis, samples that presented within the microbiological standard were classified as 1 (success) and samples that did not present 0 (failure). The chi-square test at $5.0 \%$ level or Fisher's exact test at the $5.0 \%$ level were used to compare proportions of success and failure results. The sites from which the samples were collected received ratings from Japanese food restaurants or nonspecialized establishments. The results obtained were converted into the logarithm of $x+1$ and student $t$ test was use verify whether or not there is difference in the occurrence of microorganisms in the products commercialized in the two types of establishments (SAS, 2005).

\section{RESULTS AND DISCUSSION}

The results obtained, especially in microbial groups predicted by the legislation, were compared with parameters pre-established by Resolution - RDC $\mathrm{N}^{\circ}$. 12, of January 2, 2001, for raw and similar fish (BRASIL, 2001).

Table 1 shows the distribution of the in natura sushi samples according to the exponential of the populations of heterotrophic mesophilic microorganisms, classified according to the type of establishment where the sushi was acquired.

In Brazilian legislation there is no defined limit on the acceptable number of mesophilic microorganisms, so a comparison was made with values cited in the literature. According to International Commission on Microbiological Specifications for Foods - ICMSF (2009), the mesophilic microorganisms population found in a food is one of the indicators of its quality, and should not exceed $10^{6} \mathrm{CFU} \cdot \mathrm{g}^{-1}$. A high population of these microorganisms may indicate excessive raw material contamination or during preparation, as well as inadequate cleaning and sanitation conditions. Thus, $20 \%$ of the analyzed samples presented values above this limit, indicating failures or lack of good manipulation practices in these products. Errors in the conservation process and transport also contribute to increase the populations of these microorganisms.

Considering mesophilic microorganisms, Gilbert et al. (2000) presented a grading scale for the 
quality of raw marine fish food where products with populations under $10^{3} \mathrm{CFU} \cdot \mathrm{g}^{-1}$ are considered suitable for consumption, between $10^{3}$ and $10^{4} \mathrm{CFU} \cdot \mathrm{g}^{-1}$ are satisfactory and above $10^{4} \mathrm{CFU} \cdot \mathrm{g}^{-1}$ are considered unsatisfactory. Taking into account this classification, it can be stated that $73,3 \%$ of the samples collected in this research correspond to products considered unsatisfactory for commercialization.
Table 2 shows the distribution of the in natura sushi samples according to the exponential of the populations of heterotrophic psychrotrophic microorganisms, classified according to the type of establishment where the sushi was acquired.

Table 1 - Exponential distribution of mesophilic heterotrophic microorganisms populations. (Jaboticabal, Ribeirão Preto and Monte Alto - SP, 2011 and 2012).

\begin{tabular}{|c|c|c|c|}
\hline \multirow{2}{*}{$\begin{array}{l}\text { Exponential of mesophilic } \\
\left.\text { microorganisms (CFU.g }{ }^{-1}\right)\end{array}$} & \multicolumn{2}{|c|}{ Number of samples (\%) } & \multirow{2}{*}{ Total $(\%)$} \\
\hline & Specialized restaurants & Non specialized restaurants & \\
\hline $10^{2}$ & $2(13.3)$ & $0(0.0)$ & $2(6.7)$ \\
\hline $10^{3}$ & $2(13.3)$ & $4(26.7)$ & $6(20.0)$ \\
\hline $10^{4}$ & $5(33.3)$ & $3(20.0)$ & $8(26.7)$ \\
\hline $10^{5}$ & $2(13.3)$ & $6(40.0)$ & $8(26.7)$ \\
\hline $10^{6}$ & $2(13.3)$ & $1(6.7)$ & $3(10.0)$ \\
\hline $10^{7}$ & $2(13.3)$ & $1(6.7)$ & $3(10.0)$ \\
\hline Total of samples & $15(100.0)$ & $15(100.0)$ & $30(100.0)$ \\
\hline
\end{tabular}

Table 2 - Exponential distribution of psychrotrophic heterotrophic microorganisms populations. (Jaboticabal, Ribeirão Preto and Monte Alto - SP, 2011 and 2012).

\begin{tabular}{cccc}
\hline \multirow{2}{*}{$\begin{array}{c}\text { Exponential of psychrotrophic } \\
\text { microorganisms }\left(\mathrm{CFU}_{\mathrm{g}}{ }^{-1}\right)\end{array}$} & \multicolumn{2}{c}{ Number of samples (\%) } & Total (\%) \\
\cline { 2 - 3 } & $\begin{array}{c}\text { Specialized } \\
\text { restaurants }\end{array}$ & Non specialized restaurants & \\
\hline $10^{2}$ & $0(0.0)$ & $1(6.7)$ & $1(3.3)$ \\
$10^{3}$ & $2(13.3)$ & $2(13.3)$ & $8(13.3)$ \\
$10^{4}$ & $6(40.0)$ & $2(13.3)$ & $8(26.7)$ \\
$10^{5}$ & $4(26.7)$ & $4(26.7)$ & $5(16.7)$ \\
$10^{6}$ & $1(6.7)$ & $4(26.7)$ & $2(6.7)$ \\
$10^{7}$ & $1(6.7)$ & $1(6.7)$ & $1(3.3)$ \\
$10^{8}$ & $0(0.0)$ & $0(0.7)$ & $1(3.3)$ \\
$10^{9}$ & $1(6.7)$ & $15(100.0)$ & $30(100.0)$ \\
\hline
\end{tabular}

In Brazilian legislation, there is also no defined limit regarding the acceptable number of psychrotrophic microorganisms. According to the ICMSF (2009) the limit for populations of psychrotrophic microorganisms in food is $10^{7} \mathrm{CFU} \cdot \mathrm{g}^{-1}$. Taking into account this parameter, it can be stated that $13.3 \%$ of the samples collected correspond to unsatisfactory products for commercialization.

According to Reinbold (1983), aerobic psychrotrophic microorganisms population evaluates the deterioration degree of refrigerated food. Considering that for psychrotrophic microorganisms values above $10^{4} \mathrm{CFU} \cdot \mathrm{g}^{-1}$ are relatively high, and that sushi is a food with high deterioration potential (being prepared manually and presenting raw fish as an ingredient), $83,3 \%$ of the samples would not have a long shelf-life under refrigeration.
Table 3 refers to the distribution of in natura sushi samples according to the exponential population of Staphylococcus spp.

Among the 30 analyzed samples all presented Staphylococcus spp. Bacteria of this genus are part of the normal human skin microbiota and food contamination may occur during handling, especially when protective equipment and appropriate forms of asepsis are not used. Sushi is a food that traditionally is handmade, making it a product with high potential of contamination with this microorganism.

Table 4 presents the results of coagulase positive staphylococci populations in the in natura sushi samples, distributed according to the type of establishments in which they were acquired and the samples in which the presence of Staphylococcus aureus was confirmed. 
Table 3 - Exponential distribution of spp populations. (Jaboticabal, Ribeirão Preto and Monte Alto - SP, 2011 and 2012 ).

\begin{tabular}{|c|c|c|c|}
\hline \multirow{2}{*}{$\begin{array}{l}\text { Exponential of Staphylococcus } \\
\text { sp populations. }\left(\mathrm{CFU} \cdot \mathrm{g}^{-1}\right)\end{array}$} & \multicolumn{2}{|c|}{ Number of samples (\%) } & \multirow{2}{*}{ Total (\%) } \\
\hline & Specialized restaurants & Non specialized restaurants & \\
\hline $10^{2}$ & $2(13.3)$ & $1(6.7)$ & $3(10.0)$ \\
\hline $10^{3}$ & $10(66.7)$ & $8(53.3)$ & $18(60.0)$ \\
\hline $10^{4}$ & $2(13.3)$ & $5(33.3)$ & $7(23.3)$ \\
\hline $10^{5}$ & $1(6.7)$ & $1(6.7)$ & $2(6.7)$ \\
\hline Total of samples & $15(100.0)$ & $15(100.0)$ & $30(100.0)$ \\
\hline
\end{tabular}

Table 4 - Populations of coagulase positive Staphylococcus and the samples in which the presence of S. aureus was confirmed. (Jaboticabal, Ribeirão Preto and Monte Alto - SP, 2011 and 2012).

\begin{tabular}{ccc}
\hline Sample number & $\begin{array}{c}\text { Specialized establishments } \\
\left(\text { Pop. CFU.g }{ }^{-1}\right)\end{array}$ & $\begin{array}{c}\text { Confirmed } \\
\text { Staphylococcus } \\
\text { aureus }\end{array}$ \\
\hline 1 & $7.5 \times 10^{4} *$ & $*$ \\
4 & $4.5 \times 10^{2}$ & $*$ \\
10 & $4.9 \times 10^{2}$ & $*$ \\
\hline 1 & non specialized establishments \\
$($ Pop. CFU.g & & \\
\hline 5 & $5.1 \times 10^{4} *$ & \\
12 & $7.4 \times 10^{2}$ & $*$ \\
\end{tabular}

* Non-standard samples for coagulase positive Staphylococcus. Value above $5.0 \times 10^{3} \mathrm{CFU} . \mathrm{g}^{-1}$ according to RDC $\mathrm{N}^{\mathrm{o}} 12$, dated January 2, 2001 (BRASIL, 2001).

Coagulase production Staphylococcus was present in 7 of the 30 samples analyzed, totaling $23,3 \%$ of the samples (Table 4). The production of coagulase is an important characteristic used to $S$. aureus identification, therefore, the Brazilian legislation indicates the research of this enzyme for the characterization of this microorganism in food. From 7 samples, only 4 had population values above $5,0 \times 10^{3} \mathrm{CFU} . \mathrm{g}^{-1}$, the maximum limit established by Brazilian the legislation. Consequently, $13,3 \%$ of the total samples analyzed would be unsatisfactory for consumption.

S. aureus has worldwide distribution and it is estimated that is found on the skin and in the nose of about $25 \%$ of healthy people and animals (CDC, 2017). According to Franco and Landgraf (2003), this microorganism is frequently associated with outbreaks of foodborne diseases. The presence of $S$. aureus (Table 4) was confirmed in 5 samples: 1, 4 and 10 from the specialized establishments group, and only in samples 1 and 12 from the non-specialized establishments group. Thus, the presence of $S$. aureus was confirmed in $16,7 \%$ of the total samples analyzed. According to Silva Júnior (2001), the research of this bacterium in food allows to evaluate the hygienic sanitary quality during its manipulation and preparation. Therefore, the positive samples found represent a risk to Public Health, reflecting the need to improve the production process of sushi, as well as to train the manipulators of this food to perform their tasks correctly.

Table 5 refers to the distribution of in natura sushi samples according to the exponential of thermotolerant coliforms (MPN.g ${ }^{-1}$ ).

Thermotolerant coliforms are bacteria that indicate fecal contamination and possible pathogenic enterobacteria presence and it is also used in food's sanitary evaluation due to the low cost of research of these microorganisms (JAY, 2005). For thermotolerant coliforms was verified that $33,3 \%$ of the samples presented values above $10^{2} \mathrm{MPN}$. $\mathrm{g}^{-1}$, the maximum limit established by Brazilian legislation for similar foods. Therefore, these samples would be considered unacceptable for consumption, showing that in some stage of the production chain process of these sushi there were failures related to good hygiene practices, which might have been during handling or obtaining of the raw material. 
Table 6 shows the samples in which Escherichia coli populations and thermotolerant coliform populations were identified, according to the type of establishment in which they were collected.

In Table 6, it is possible to observe the presence of $E$. coli in samples 1,8 and 14 of the specialized establishments group and in samples 1, 2, $5,10,11$ and 14 of the non-specialized establishments group, with populations ranging from $0,15 \times 10$ to
$7,5 \times 10 \mathrm{MPN} . \mathrm{g}^{-1}$ totaling 9 samples from the 30 analyzed $(30,0 \%)$. Several strains of this microorganism are pathogenic to humans and the presence of $E$. coli in a food confirms fecal contamination (FRANCO and LANDGRAF, 2003). Thus, $30,0 \%$ of the sushi analyzed presented fecal residues in some phase of the manipulation, storage or obtaining of the raw material.

Table 5 - Exponential distribution of thermotolerant coliform populations (NMP.g ${ }^{-1}$ ). (Jaboticabal, Ribeirão Preto and Monte Alto - SP, 2011 and 2012).

\begin{tabular}{|c|c|c|c|}
\hline \multirow{2}{*}{$\begin{array}{c}\text { Exponential of thermotolerant } \\
\left.\text { coliforms (MPN.g }{ }^{-1}\right)\end{array}$} & \multicolumn{2}{|c|}{ Number of samples (\%) } & \multirow{2}{*}{ Total $(\%)$} \\
\hline & Specialized restaurants & Non specialized restaurants & \\
\hline absence $(<3.0)$ & $8(53,3)$ & $4(26,7)$ & $12(40,0)$ \\
\hline$<10$ & $1(6,7)$ & $1(6,7)$ & $2(6,7)$ \\
\hline 10 & $2(13,3)$ & $4(26,7)$ & $6(20,0)$ \\
\hline $10^{2}$ & $1(6,7)$ & $5(33,3)$ & $6(20,0) *$ \\
\hline $10^{3}$ & $1(6,7)$ & $1(6,7)$ & $2(6,7) *$ \\
\hline $10^{4}$ & $2(13,3)$ & $0(0,0)$ & $2(6,7) *$ \\
\hline Total of samples & $15(100,0)$ & $15(100,0)$ & $30(100,0)$ \\
\hline
\end{tabular}

* Non-standard samples for thermotolerant coliforms. Value above $10^{2}$ (MPN. $\mathrm{g}^{-1}$ ) according to RDC $-\mathrm{N}^{\mathrm{o}} 12$, of January 2, 2001 (BRASIL, 2001).

Table 6 - Distribution of the samples in which Escherichia coli and thermotolerant coliforms were quantified according to the type of commercial establishment.(Jaboticabal, Ribeirão Preto and Monte Alto - SP, 2011 and 2012).

\begin{tabular}{ccc}
\hline \multirow{2}{*}{ Sample number } & \begin{tabular}{c} 
Thermotolerant coliforms population \\
\cline { 2 - 3 }
\end{tabular} & $\begin{array}{c}\text { Escherichia coli population } \\
\left(\text { Pop. MPN.g }{ }^{-1}\right)\end{array}$ \\
\hline 1 & $\left(\right.$ Pop. MPN.g $\left.{ }^{-1}\right)$ & $0,75 \times 10$ \\
8 & $4,6 \times 10^{4} *$ & $0,15 \times 10$ \\
14 & $3,6 \times 10$ & $7,5 \times 10$ \\
\hline & $1,2 \times 10^{4} *$ & $0,39 \times 10$ \\
\hline 1 & Non specialized establishments $10,15 \times 10$ \\
5 & $\left(\right.$ Pop. MPN.g $\left.{ }^{-1}\right)$ & $0,15 \times 10$ \\
10 & $2,1 \times 10^{3} *$ & $0,2 \times 10$ \\
11 & $3,6 \times 10^{2} *$ & $0,15 \times 10$ \\
14 & $3,9 \times 10^{2} *$ & $0,15 \times 10$ \\
\hline
\end{tabular}

* Non-standard samples for thermotolerant coliforms. Value above $10^{2}$ NMP.g ${ }^{-1}$ according to RDC - $\mathrm{N}^{\circ} 12$, of January 2 , 2001 (BRASIL, 2001).

Table 7 presents, in summary, the arithmetic means and standard deviations of the populations of heterotrophic mesophilic and heterotrophic psychrotrophic microorganisms, Staphylococcus sp., total coliforms and thermotolerant coliforms, distributed according to the type of establishment where the samples were collected.

The Student $t$ test was applied to the values of the microorganism populations specified in Table 7 , and from the statistical point of view there were no significant differences between the means of these populations $(\mathrm{p}>0,05)$.
At the beginning of this study, it was expected that there were significant differences between the results obtained in the two groups of restaurants studied. Specialized restaurants work only with Japanese cuisine, and many advertise strict hygiene measures during the preparation of the sushi, as well as the efficiency, quality, tradition and expertise of their sushimen. These employees are mandatorily trained in workshops to learn how to prepare good quality sushi. Non-specialized restaurants, however, work with various types of cuisine and although they require good cooks, they don't train the staff for good sanitary practices during their service. 
Table 7 - Arithmetic means and standard deviations of the populations of mesophilic and psychrotrophic microorganisms, Staphylococcus sp., total coliforms and thermotolerant coliforms. (Jaboticabal, Ribeirão Preto and Monte Alto - SP, 2011 and 2012).

\begin{tabular}{ccc}
\hline Microorganisms & \multicolumn{2}{c}{ Arithmetic means of the populations } \\
\cline { 2 - 3 } & Specialized & Non specialized \\
\hline Heterotrophic Mesophilic & $2,0 \times 10^{6} \pm 4,6 \times 10^{6}$ & $1,8 \times 10^{6} \pm 4,6 \times 10^{6}$ \\
Psychrotrophic & $9,4 \times 10^{7} \pm 3,6 \times 10^{8}$ & $1,1 \times 10^{7} \pm 3,3 \times 10^{7}$ \\
Staphylococcussp. & $3,5 \times 10^{4} \pm 9,8 \times 10^{4}$ & $3,3 \times 10^{4} \pm 6,7 \times 10^{4}$ \\
Total coliforms & $1,6 \times 10^{4} \pm 3,8 \times 10^{4}$ & $4,9 \times 10^{3} \pm 1,2 \times 10^{4}$ \\
Thermotolerant coliforms & $4,0 \times 10^{3} \pm 1,2 \times 10^{4}$ & $2,9 \times 10^{2} \pm 5,6 \times 10^{2}$ \\
\hline
\end{tabular}

However, the results obtained at the end of this study showed that there were no differences in the quality of the sushi offered to the consumer by the two types of restaurants. Although all the samples analyzed presented excellent visual appearance when collected, the high amounts of heterotrophic mesophilic and psychrotrophic microorganisms, and relatively high populations of total and thermotolerant coliforms reflect inadequate hygienic and sanitary conditions during preparation, handling, or even low-quality raw material used by the commercial establishments. This diagnosis demonstrates the deficiency of the governmental inspection agencies that should be controlling the quality of these products, as well as the lack of training and qualification of food professionals.

Another important factor observed in this study was the presence of $S$. aureus and $E$. coli. These microorganisms are important for Public Health because, under ideal conditions for their multiplication, they can cause severe illnesses, being able to affect great part of consumers.

$V$. parahaemolyticus and microorganisms of the Salmonella genus were not found in any of the analyzed samples. Therefore, all samples were kept within the established standard, which is defined by absence of Salmonella spp. in $25.0 \mathrm{~g}$ of the food and a maximum limit of $10^{3} \mathrm{MPN} . \mathrm{g}^{-1}$ for $V$. parahaemolyticus in dishes that contain raw fish (BRASIL, 2001).

Vallandro (2011), at the end of his work, reported that the most probable source of contamination by Salmonella spp. and $V$. parahaemolyticus in salmon sashimi is the place of fish breeding and/or capture. The fact that the raw material used by the restaurants have well-known origin and are imported from inspected establishments probably contributed to the absence of these microorganisms. As all samples analyzed in this study were necessarily consisted of salmon, the same conclusion can be adopted to explain the absence of these pathogens. It is important to note that sushi, unlike sashimi, is a food composed of several ingredients. Thus, contamination by Salmonella spp. could also occur through eggs, sauces, cheeses, vegetables and other varieties of components used for their preparation.

Regarding $V$. parahaemolyticus, Vallandro (2010), presents a hypothesis that the absence of this microorganism in sashimi can be related to the fact that the salmon consumed in Brazil is bred in cold waters, mainly in Chile. According to Forsythe (2013) it is probable that this characteristic contributes to the low occurrence of the bacterium or its low presence in the fish, since $V$. parahaemolyticus is normally present in quantities greater than $10^{3} \mathrm{CFU} . \mathrm{g}^{-1}$ in fish and seafood proceeding from warm waters. In addition, the salmon consumed is transported frozen to Brazil, which is also adverse to the bacteria survival, according to Cook and Ruple (1992).

Table 8 presents a summary of the nonstandard samples for coagulase positive Staphylococcus and thermotolerant coliforms, distributed according to the type of establishment where the samples were acquired.

Table 8 - Non-standard samples for coagulase positive Staphylococcus and thermotolerant coliforms, according to the parameters established by RDC - $\mathrm{N}^{\mathrm{o}} 12$, of January 2, 2001 for similar foods, distributed according to the type of establishment where they were collected. (Jaboticabal, Ribeirão Preto and Monte Alto - SP, 2011 and 2012).

\begin{tabular}{|c|c|c|c|}
\hline \multirow{2}{*}{ Microorganisms } & \multicolumn{2}{|c|}{ Non-standard samples } & \multirow{2}{*}{ Total $(\%)$} \\
\hline & Specialized & Non-specialized & \\
\hline $\begin{array}{l}\text { coagulase positive } \\
\text { Staphylococcus }\end{array}$ & $1(\mathrm{~A} 1)$ & $3(\mathrm{~A} 1, \mathrm{~A} 6$ e $\mathrm{A} 12)$ & $4(13.3)$ \\
\hline thermotolerant coliforms $* *$ & $4(\mathrm{~A} 1, \mathrm{~A} 12, \mathrm{~A} 14$ e A15) & $6(\mathrm{~A} 1, \mathrm{~A} 2, \mathrm{~A} 4, \mathrm{~A} 5, \mathrm{~A} 6$ e A10) & $10(33.3)$ \\
\hline $\begin{array}{c}\text { Non-standard samples for } \\
\text { both microorganisms }\end{array}$ & $1(\mathrm{~A} 1)$ & $2(\mathrm{~A} 1 \mathrm{e} \mathrm{A} 12)$ & $3(10.0)$ \\
\hline $\begin{array}{c}\text { Total of non-standard } \\
\text { samples } \\
\end{array}$ & 4 (A1, A12, A14 e A15) & $\begin{array}{c}7(\mathrm{~A} 1, \mathrm{~A} 2, \mathrm{~A} 4, \mathrm{~A} 5, \mathrm{~A} 6, \mathrm{~A} 10 \mathrm{e} \\
\mathrm{A} 12)\end{array}$ & $11(36.6)$ \\
\hline
\end{tabular}

$*$ Value above $5.0 \times 10^{3} \mathrm{CFU} . \mathrm{g}^{-1}$. ** Value above $10^{2} \mathrm{MPN} \cdot \mathrm{g}^{-1}$ 
Fisher's exact test was applied between the groups of specialized and non-specialized establishments, comparing the standard and non-standard samples for coagulase positive Staphylococcus and thermotolerant coliforms. As results, there were no statistically significant differences between the two groups of establishments ( $p$ > $0,05)$, therefore, there were no differences in the frequencies found between the standard and non-standard samples for the two types of establishments, concerning the microorganisms.

At the end of this work, it was verified that the total of non-standard samples were $11(36,6 \%)$. The chisquare test was applied between the groups of specialized and non-specialized establishments, comparing the standard and non-standard samples. As a result, there was no statistically significant difference between the groups of establishments $(\mathrm{x} 2<\mathrm{x} 2 \mathrm{c}=0,05)$, therefore, the frequencies found between the standard and non-standard samples for the 2 types of restaurants were the same.

\section{CONCLUSIONS}

The results of this work suggest that sushi can potentially cause foodborne diseases since microbiological isolation and biochemical confirmations of the agents $S$. aureus and $E$. coli were possible. These data, added to the amount of non-standard samples found, reflect the need to invest in the training of food handlers in order to raise awareness of how and why to produce food with good hygienic sanitary quality.

The present study also demonstrates the importance of continuing, and deepening the studies on the subject. Japanese food has gained prominence in Brazil, and sushi is a much manipulated food that has several ingredients, one of them being raw material. Therefore, there is a need to study the entire sushi production chain to identify the critical points and seek solutions aiming at the production of a healthy and safe food for the society.

\section{ACKNOWLEDGEMENTS}

The authors are grateful to the São Paulo Research Foundation (FAPESP) for financial support (2011/ 14368-4).

\section{REFERENCES}

APHA. American Public Health Association. Committee on Microbiological for Foods. Compendium of methods for the microbiological examination of foods. 4. ed. Washington, 2001. $676 \mathrm{p}$.

BRASIL. Agência Nacional de Vigilância Sanitária. Resolução - RDC n⿳12, de 2 de janeiro de 2001. Disponível em: <http://portal.anvisa.gov.br/documents/33880/2568070/R DC_12_2001.pdf/15ffddf6-3767-4527-bfac-

740a0400829b>. Acesso em: 20 out. 2012.
CDC. Center for Disease Control and Prevention. Staphylococcal Food Poisoning . 2015. Disponível em: <https://www.cdc.gov/foodsafety/diseases/staphylococcal .html>. Acesso em: 29 abr. 2017.

COOK, D. W.; RUPLE, A. D. Cold Storage and Mild Heat Treatment as Processing Aids to Reduce the Numbers of Vibrio vulnificus in Raw Oysters. Journal of Food Protection. v.55, n.12, p.985-989. 1992.

FORSYTHE, Stephen J. Microbiologia da segurança dos alimentos. 2 ed. Porto Alegre: Artmed, 2013.

FRANCO, B. D. G. M.; LANDGRAF, M. Microbiologia de alimentos. São Paulo: Atheneu, 2003. 182 p.

GILBERT, R. J.; LOUVOIS, J.; DONOVAN, T.; LITTLE, C.; NYE, K.; RIBEIRO, C. D.; RICHARDS, J.; ROBERTS, D.; BOLTON, F. J. Guidelines for the microbiological quality of some ready-to-eat foods samples at the point of sale. Communicable Disease Public Health, London, v.3, n.3, p.163-167, 2000.

ICMSF. International Commission on Microbiological Specifications for Foods. Microrganismos em alimentos. Edição 8. São Paulo: Blucher, 2009. 536p

JAY, J. M. Microbiologia de alimentos. 6. ed. Porto Alegre: Artmed, 2005. 712 p.

REINBOLD, G.W. Indicator organisms in dairy products. Food Technology, Chicago, v.37, n.6, p.111-113, 1983.

SAS INSTITUTE. User’s guide: statistics. Cary, 2005.

SILVA JÚNIOR, E. A. Manual higiênico sanitário de alimentos. 4. ed. São Paulo: Varela, 2001. p.477.

VALLANDRO, M. J. Avaliação da qualidade microbiológica de sashimis a base de salmão, preparados em restaurantes especializados em culinária japonesa na cidade de Porto Alegre - RS. 2010. 67 f. Dissertação (Mestrado em Ciências Veterinárias na área de Bacteriologia) - Universidade do Rio Grande do Sul, Porto Alegre, 2010.

VALLANDRO, M. J.; CAMPOS, T.; PAIM, D.; CARDOSO, M.; KINDLEIN, L. Avaliação da qualidade microbiológica de sashimis à base de salmão, preparados em restaurantes especializados em culinária japonesa. Revista do Instituto Adolfo Lutz, São Paulo, v.70, n.2, p.144-150, 2011. 